\title{
New Media Classroom Teaching of College Ideological and Political Course with Innovation
}

\author{
Zhou Xianyang \\ Yunnan Land and Resources Vocational College, Yunnan, Kunming, 650118
}

Keywords: college ideological and political course, new media classroom teaching, innovative teaching

\begin{abstract}
With the development of information technology and the progress of network era, in the process of carrying out ideological and political education, colleges and universities pay more and more attention to the implementation of new media and innovative teaching now. In the process of ideological and political education, it is combined with the continuous development of society as well as science and technology, and puts forward the pertinent and innovative teaching mode to promote the development of college students' comprehensive quality and progress and improve the ideological and political teaching in colleges. In constant innovation and development of new media teaching, teachers should constantly update their teaching concept and teaching mode, actively use the network informatization means to expand the network teaching environment, build innovative, comprehensive and efficient mode of ideological and political teaching, enrich the contents of the ideological and political teaching and improve students' ideological and political study. In order to analyze the approaches and teaching measures of innovative new media classroom teaching of ideological and political course, the paper analyzes the problems existing in the teaching process of ideological and political course and the significance of implementing innovative teaching.
\end{abstract}

\section{Introduction}

New media belongs to the new media form emerging in the current network information technology environment and rapidly developing. In the college ideological and political education, the implementation of new media classroom teaching mainly includes new media teaching plan, new media courseware, new media exercises, new media teaching audio and video, new media interactive content, etc. [1]. New media classroom teaching focuses on teaching resource sharing and communication, and in the process of teaching, it realizes the sensory stimulation of students mainly through text and image, audio and video, etc., which has a strong attraction, influence and value of infection, so as to enhance students' learning interest and learning efficiency. It has laid a good foundation for improving students' comprehensive quality.

\section{The Problems Existing in the Current College Ideological and Political Education}

There are some serious problems in the process of ideological and political teaching in colleges at present, which are mainly reflected in the following aspects: a. traditional teaching content and teaching approach: Because of the influence of various factors in the process of the traditional teaching, there are some limitations in teaching content, teaching form and teaching environment of college ideological and political education. In the learning process, students can only obtain more knowledge of ideological and political education through textbook and self-searching. In the teaching, teachers still use the infusing teaching method. Also, teaching content of ideological and political education is boring to some extent, resulting in a decline in the students' interest in learning, so it is unable to attract the attention of students, which is not conducive to the improvement of college ideological and political teaching level. b. Students' poor ideology and autonomous learning consciousness: because of the influence of the traditional teaching system, students just passively accept knowledge in the process of ideological and political education in colleges at present [2]. The differences between social reality and theoretical knowledge of books 
let students feel disoriented, which is unable to cultivate students' scientific and accurate values. Students have poorer self-learning and exploration consciousness in the process of the traditional teaching, which is not conducive to the improvement of ideological and political education in colleges. c. There is an uncoordinated development between teaching environment and teaching mode: Under the continuous development of the information age, new media has become more important in the process of students' learning and life, largely changing the college students' lifestyle, way of thinking and ideas. New media age and network information technology has brought great convenience to students' life and study, but the present teaching system and teaching form can't keep up with the development of the new media class requirements. Both present a mismatch phenomenon, making the efficiency of ideological and political teaching lower, thereby seriously influencing students’ learning level and learning efficiency [3].

\section{Significance of Implementing Innovative Teaching, Approaches and Teaching Measures of New Media Teaching of Ideological and Political Course}

In the process of classroom teaching in college ideological and political course, the implementation of innovative teaching has openness to extend teaching space to a certain extent and enriches the teaching content. In the process of new media classroom teaching, it enhances the communication and interaction between teachers and students to some extent, which is convenient for teachers to combine the practical situation of students to give specific guidance. In the new media classroom teaching, teachers can guide social hot topics and real events related to ideological and political course, which can enhance students' learning motivation and learning interest, and meet college ideological and political classroom teaching requirements. In the new media classroom teaching, innovation teaching way can partly improve the interactions between teachers and students, and build a harmonious, equal and free study atmosphere. The information exchange in new media classroom teaching of college ideological and political course is mainly interaction of students in the form of network communication, which provides a certain way and feasibility to realize the equality between teachers and students in interaction, promotes the cultivation of students' independent character and personality [4], and improves the comprehensive quality of students. Compared with traditional teaching that students just gain knowledge from textbooks, new media classroom teaching innovation will use the latest information technology for information processing to provide intuitive and detailed visual and auditory feeling for students, meet the demand of personalized learning for students of different learning levels, effectively improve the traditional teaching mode that focuses on theory and ignores practice, improve ideological and political teaching level in colleges, and promote the cultivation and development of students' comprehensive quality.

In the process of traditional ideological and political teaching, it mainly focuses on the interpretation of the theoretical contents of ideological and political by teachers, and students follow the teacher in the classroom to passively accept knowledge, group discussion and mechanical practice, which is not conducive to the embodiment of students as main teaching body. In this study condition and the teaching idea, students' learning enthusiasm is low, with low interest in learning, leading to poorer ideological and political teaching level [5]. Therefore, in the new media teaching process of ideological and political course, innovation teaching concept is the primary one for innovative teaching. Teachers should change the teaching form with self as dominant body, but give full play to their role as teaching guide, organizer in the new media teaching process, combined with the teaching content and new media technology to carry out a free and harmonious classroom teaching and guide students' autonomous learning. In class, after putting forward the problems and difficulties in the process of autonomous learning, organize the students are organized to explore and discuss independently, and finally the teacher summarize students' discussion results, so as to improve students' subjective initiative, awareness of participating in learning, create a harmonious and positive learning atmosphere, enhance students' interest and confidence in learning, and promote students to form a sound and scientific ideological and political concept in the teaching process of new media [6]. 
In the process of ideological and political education in colleges, teachers should pay attention to combining the developing direction of the new media age to realize the synchronous progress and innovation, attach great importance to students' actual level of learning, add the contents related to the construction of socialism with Chinese characteristics in the process of classroom teaching, guide students to understand and memorize new information in combination with the teaching content, or guide students to use knowledge to solve and analyze the problems existing in the real life. Through sharing and communicating teaching resources in the new media classroom, students' ideological and political level and comprehensive quality are cultivated, so as to help students to master, consolidate and familiarize the ideological and political teaching knowledge points they have learned [7]. In addition, teachers can also organize students to put theory into practice in the process of teaching, promote students to make pertinent analysis, skilled master and understanding of the knowledge in the process of ideological and political teaching. Through the study in the ideological and political content, students can solve practical problems in the process of life, improve the learning ability of students to integrate theory with practice, and arouse students' enthusiasm and practice.

In the process of college ideological and political classroom teaching, teachers should take advantage of new media teaching to build the practical teaching mode of combining online and offline learning, with diversified teaching methods to attract the attention of students. Teachers can collect valuable and meaningful micro lesson video on the network, APP, learning platforms of high-quality ideological and political teaching website, provide students with extensive and in-depth learning in combination of books. By watching video online, teachers can realize free exchange with students in the same WeChat group to improve students' ability to solve problems and grasp ideological knowledge. In combination of college students' interests, teachers make microblog hot topics, current political affairs imparted in the process of classroom teaching, guide students to recall what they have learned to make the corresponding analysis and investigation on the events, combine the real life events with ideological and political content for teaching, make the corresponding micro lesson video shared in WeChat group, help students to analyze the events in theoretical study, consolidate theory knowledge in the event discussion, cultivate students to distinguish the right and the wrong, scientific values, outlook on life and world view, and promote the development of students' comprehensive quality [8].

\section{Conclusion}

In the process of college ideological and political classroom teaching, innovative college ideological and political teaching concept is carried out based on the analysis of students' learning needs and current college ideological and political teaching requirements, to improve the traditional teaching mode; through new media classroom information resources, it enriches classroom teaching content, establishes teaching combining theory with practice and fully takes advantage of new media teaching innovation in college ideological and political education, so as to promote the improvement of students' ideological and political learning, and the development of their comprehensive quality.

\section{References}

[1] Ji Liling. Innovative exploration of teaching methods of ideological and political course in colleges under the new media environment. Studies in Ideological Education, 2016, 13 (10):82-85.

[2] Wang Zhiyu. Exploring the innovative path of college ideological and political course reform under the new media environment. Journal of literature review, 2007, 22(22).30-31.

[3] Li-Li L I, University S N. Reflection on the Problems of Ideological and Political Course Teachers in Colleges and Universities in Response to the Students' Evaluation of Teaching. Education Modernization, 2016.

[4] Nong Shuying. Reflection on practical teaching in ideological and political theory course in 
colleges by using new media innovation. Journal of Hezhou University, 2015, 33 (2):124-127.

[5] Hou Yanyan. Change at Times, Following Laws and Reform and innovation -- some thoughts on teaching method innovation in ideological and political course in colleges. Journal of ideological \& theoretical education, 2017, 05 (9):112-114.

[6] Wang Shuangqun. Thoughts on innovative teaching methods of ideological and political course in the new media environment. Journal of ideological \& theoretical education, 2015, 35 (11): 111-115.

[7] Ji Qizuo. Innovation in teaching methods of ideological and political course in colleges under the new media environment. Literature education, 2017, 15 (10):171-171.

[8] Zhang Xishun. Transposition thinking: reform and innovation of ideological and political teaching in colleges from the perspective of students. Journal of higher education, 2008, 24(2): 21-23. 